\title{
Observation of Potential Contaminants in Processed Biomass Using Fourier Transform Infrared Spectroscopy
}

\author{
Jingshun Zhuang ${ }^{1}$, $\mathrm{Mi} \mathrm{Li}^{2}$, Yunqiao $\mathrm{Pu}^{3}$, Arthur Jonas Ragauskas ${ }^{2,3,4, *(D)}$ \\ and Chang Geun Yoo ${ }^{1,3, * \mathbb{D}}$ \\ 1 Department of Chemical Engineering, State University of New York College of Environmental Science and \\ Forestry, Syracuse, NY 13104, USA; jzhuan02@syr.edu \\ 2 Center for Renewable Carbon, Department of Forestry, Wildlife, and Fisheries, University of Tennessee \\ Institute of Agriculture, Knoxville, TN 37996, USA; mli47@utk.edu \\ 3 Center for Bioenergy Innovation, Biosciences Division, University of Tennessee-Oak Ridge National \\ Laboratory Joint Institute for Biological Science, Oak Ridge National Laboratory, Oak Ridge, TN 37831, USA; \\ puy1@ornl.gov \\ 4 Department of Chemical and Biomolecular Engineering, University of Tennessee, Knoxville, TN 37996, USA \\ * Correspondence: aragausk@utk.edu (A.J.R.); cyoo05@esf.edu (C.G.Y.)
}

Received: 2 June 2020; Accepted: 22 June 2020; Published: 24 June 2020

\begin{abstract}
With rapidly increased interests in biomass, diverse chemical and biological processes have been applied for biomass utilization. Fourier transform infrared (FTIR) analysis has been used for characterizing different types of biomass and their products, including natural and processed biomass. During biomass treatments, some solvents and/or catalysts can be retained and contaminate biomass. In addition, contaminants can be generated by the decomposition of biomass components. Herein, we report FTIR analyses of a series of contaminants, such as various solvents, chemicals, enzymes, and possibly formed degradation by-products in the biomass conversion process along with poplar biomass. This information helps to prevent misunderstanding the FTIR analysis results of the processed biomass.
\end{abstract}

Keywords: poplar; FTIR; contaminants; by-products

\section{Introduction}

A proper understanding of biomass characteristics is important for the effective utilization of biomass. It not only provides natural properties of biomass but also tells the influences of the applied processes on the biomass structures. Characteristics of biomass have been investigated in different aspects, including physical, chemical, thermal, mineral, and surface properties. For a better understanding of biomass and its products, several different analytical approaches have been developed using diverse analytical techniques such as high-performance liquid chromatography (HPLC), gas chromatography (GC), gel permeation chromatography (GPC), nuclear magnetic resonance (NMR), time-of-flight secondary ion mass spectrometry (ToF-SIMS), X-ray, transmission electron microscopy (TEM), scanning electron microscopy (SEM), differential scanning calorimetry (DSC), thermogravimetric analysis (TGA), and Fourier transform infrared (FTIR) for measuring carbohydrate contents, identification and quantity of products, molecular weights, structural information such as linkages and composition, spatial distribution of molecules and chemical structures on surface, crystallinity, morphological characteristics in nano- and micro-scales, thermal properties (melting point, glass transition temperature, etc.), functional groups and chemical bonds, and other important information of biomass and its products and by-products [1-9]. Among these methods, 
FTIR spectroscopy is one of the most widely applied analytical methods to study the functional groups of biomass by measuring the absorption bands of samples [10]. It provides qualitative and semi-quantitative information for functional groups of biomass by determining the presence of fundamental molecular vibrations [11]. Its Fellgett and Jacquinot advantages allow for rapid and ready characterization compared to many other biomass analysis methods [12]. Moreover, it does not need any modification and/or deconstruction of biomass; therefore, original properties can be monitored as the sample is. Despite these advantages, the characterization of biomass using FTIR is still challenged by overlapping the bands from different biomass components and/or unexpected impurities from the applied catalysts and solvents. In particular, fingerprint regions are complicated to identify because of many series of absorptions. For fast and reliable analysis of the substances from different processing, detection, and identification of possible contaminants are very important.

Lignocellulosic biomass is a heterogeneous matrix. Due to the complicated composition and structural properties of biomass, single or multi-stage pretreatment/preprocessing is necessary for its utilization, isolation, and analyses. Various chemicals, such as organic solvents, acids, alkalis, and inorganic salt solutions have been applied for isolation, pretreatment, conversion, and other reactions on biomass [13-19]. Biological catalysts, such as enzymes, have also been used in many biomass conversion processes or characterization methods [20]. Besides, each biomass component could be decomposed and/or modified under severe process conditions [21]. The presence of these chemicals and by-products are considered as impurities and could potentially affect their characterization results; therefore, they should be completely removed after the processes. Unfortunately, these components are possibly retained on the surface of biomass after these preprocessing and cause misinterpretation of the targeted biomass structure by their overlapped FTIR spectra. Besides the misreading of the biomass properties, the detection of contaminants can be used to determine the necessity of biomass washing step. Although the IR assignments of many chemicals and solvents are available individually, their actual contaminations are not easily detected due to the spectra of biomass itself. In this study, poplar biomass was mixed with known chemicals and enzymes, which are potential contaminants, and their overlapped FTIR spectra in each sample were identified and discussed.

\section{Materials and Methods}

\subsection{Materials}

Poplar was harvested in the Oak Ridge National Laboratory in 2008. Prior to the FTIR analysis, the sample was Wiley-milled and screened to $0.42 \mathrm{~mm}$. Extractives were removed from the original poplar sample ( 10 g) by toluene/ethanol Soxhlet extraction $(2: 1, v / v, 200 \mathrm{~mL})$ for $8 \mathrm{~h}$ followed by $6 \mathrm{~h}$ of water extraction. All chemicals (acetone, ethanol, methanol, tetrahydrofuran, dioxane, toluene, glycerol, chloroform, pyridine, sulfuric acid, hydrochloric acid, phosphoric acid, acetic acid, sodium hydroxide, ammonium hydroxide, 1-butyl-3-methylimidazolium chloride, 1-benzyl-3-methylimidazolium chloride, choline chloride, urea, $p$-hydroxybenzoic acid, 4-hydroxybenzaldehyde, $p$-coumaric acid, hydroxymethylfurfural, and furfural) and enzymes (cellulase and $\beta$-glucosidase) used in this study were purchased from VWR, Sigma-Aldrich, or Fisher Scientific. Deep eutectic solvents (DESs) formed by combining hydrogen bonding donors (HBDs: urea, $p$-hydroxybenzoic acid, 4-hydroxybenzaldehyde, $p$-coumaric acid) and hydrogen bonding acceptor (HBA: choline chloride) at $80{ }^{\circ} \mathrm{C}$ prior to the FTIR analysis.

\subsection{Isolation of Cellulose, Hemicellulose, and Lignin}

Cellulose, hemicellulose, and lignin were isolated from the extractives-free poplar, as described in the previous studies [2,22]. In brief, the biomass was delignified using peracetic acid at $25{ }^{\circ} \mathrm{C}$ with $5 \%$ $(\mathrm{wt} / \mathrm{wt}$ ) solid loading for $24 \mathrm{~h}$. The remaining solid, holocellulose, was air dried for $24 \mathrm{~h}$. Two-step alkali extraction with $17.5 \%(\mathrm{wt} / \mathrm{wt})$ and $8.75 \%(\mathrm{wt} / \mathrm{wt})$ sodium hydroxide was conducted at $25^{\circ} \mathrm{C}$ for $2 \mathrm{~h}$ in each step. The remaining solid fraction was called $\alpha$-cellulose after being air dried, and the 
liquid fraction was neutralized with anhydrous acetic acid and mixed with ethanol three times to precipitate hemicellulose.

Cellulolytic enzyme lignin (CEL) was separated from the poplar samples. The extractives-free poplar was ball-milled using Retsch PM 100 at $600 \mathrm{rpm}$ for $2 \mathrm{~h}$. The ball-milled sample was hydrolyzed at $50{ }^{\circ} \mathrm{C}$ with the $\mathrm{CTec} 2$ enzyme in acetate buffer solution ( $\mathrm{pH} 4.8$ ) for $48 \mathrm{~h}$ twice. The residual solid was extracted with $96 \%$ dioxane for $48 \mathrm{~h}$. The dioxane-extracted fraction was recovered at $40{ }^{\circ} \mathrm{C}$ by rotary evaporation and freeze drying and used for further analysis.

\subsection{Fourier Transform Infrared (FTIR) Analysis}

To observe the FTIR spectra of contaminants from the spectra of biomass clearly, about 30-50 $\mu \mathrm{L}$ of contaminant was loaded to $0.3 \mathrm{~g}$ of extractives-free poplar in $20 \mathrm{~mL}$ glass vial and mixed by vortexing prior to the analysis. The prepared DESs were loaded to biomass and physically mixed using a glass rod due to their relatively high viscosity. FTIR analysis was conducted using the Spectrum One FTIR spectrometer (PerkinElmer, Wellesley, MA, USA) equipped with a universal attenuated total reflection (ATR) accessory. ATR-FTIR spectra between 4000 and $600 \mathrm{~cm}^{-1}$ were measured at a $4 \mathrm{~cm}^{-1}$ resolution and averaging 16 scans per sample.

\section{Results and Discussion}

\subsection{Major Components of Biomass}

Cellulose, hemicellulose, and lignin are three main components in lignocellulosic biomass. Table 1 and Figure 1 present the FTIR band assignments and spectra of poplar and its major components isolated from the same biomass. Prior to the analysis, other extractives in the poplar sample were removed by two-step extraction: $8 \mathrm{~h}$ toluene/ethanol Soxhlet-extraction followed by $6 \mathrm{~h}$ water extraction. Isolated cellulose, hemicellulose, and lignin were analyzed using FTIR and compared with the extractives-free poplar. The assignment of each band was identified according to the previous studies [23-31].

Table 1. Fourier transform infrared (FTIR) band assignments of poplar and its major components: cellulose, hemicellulose, and lignin [23-31].

\begin{tabular}{|c|c|c|c|}
\hline & Wavenumber $\left[\mathrm{cm}^{-1}\right]$ & Assignment & Components \\
\hline 2 & 2914 & C-H stretching & Cellulose, Hemicellulose, Lignin \\
\hline 3 & 1745 & $\mathrm{C}=\mathrm{O}$ stretching & Hemicellulose, Lignin \\
\hline 4 & 1618 & Aromatic skeletal vibration, $\mathrm{C}=\mathrm{O}$ stretching, adsorbed $\mathrm{O}-\mathrm{H}$ & Hemicellulose, Lignin \\
\hline 5 & 1508 & $\mathrm{C}=\mathrm{C}-\mathrm{C}$ aromatic ring stretching and vibration & Lignin \\
\hline 6 & 1457 & C-H deformation (in methyl and methylene) & Lignin \\
\hline 8 & 1370 & $\mathrm{C}-\mathrm{H}$ bending, $\mathrm{C}-\mathrm{H}$ stretching in $\mathrm{CH}_{3}$ & Cellulose, Hemicellulose, Lignin \\
\hline 9 & 1317 & $\mathrm{CH}_{2}$ wagging, $\mathrm{C}-\mathrm{O}$ stretching of $\mathrm{C}_{5}$ substituted aromatic units & Cellulose, Hemicellulose, Lignin \\
\hline 10 & 1235 & C-O stretching of guaiacyl unit & Lignin \\
\hline 11 & 1160 & C-O-C stretching & Cellulose, Hemicellulose \\
\hline 12 & 1108 & Aromatic $\mathrm{C}-\mathrm{H}$ in plane deformation & Lignin \\
\hline 13 & 1053 & C-OH stretching vibration, $\mathrm{C}-\mathrm{O}$ deformation & Cellulose, Hemicellulose, Lignin \\
\hline
\end{tabular}




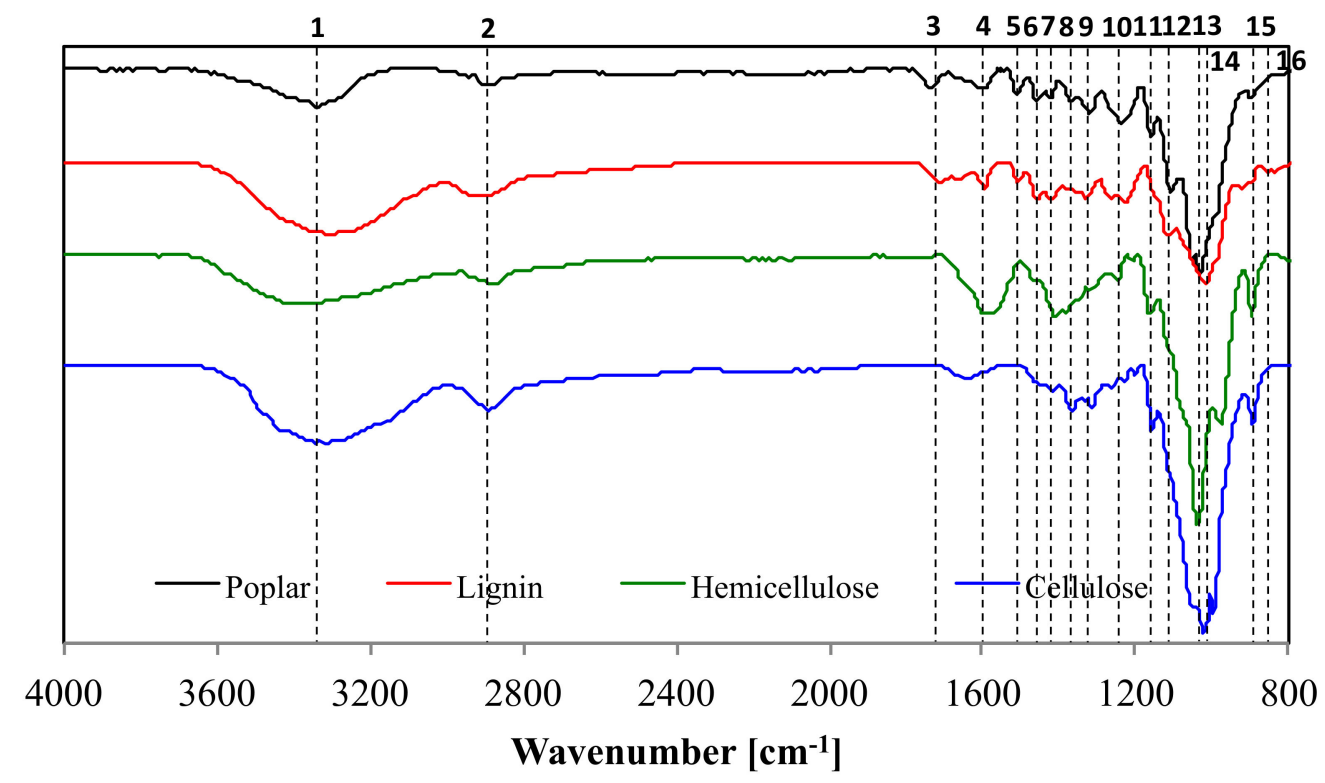

Figure 1. FTIR spectra of poplar and its major components: cellulose, hemicellulose, and lignin. (Note: The assignments of the numbered bands in the figure are described in Table 1).

The IR spectra of poplar and its components showed strong O-H stretching and C-H stretching absorptions at 3367 and $2914 \mathrm{~cm}^{-1}$, respectively. These two strong absorptions are because all three major components in biomass (cellulose, hemicellulose, and lignin) have hydroxy groups and many $\mathrm{C}-\mathrm{H}$ bonds in their structures. The absorption at $1745 \mathrm{~cm}^{-1}$ was due to $\mathrm{C}=\mathrm{O}$ stretching in hemicellulose and lignin. The absorption at $1618 \mathrm{~cm}^{-1}$ represented asymmetric stretching band of the carboxyl group of glucuronic acid in hemicellulose and $\mathrm{C}=\mathrm{O}$ stretching in conjugated carbonyl of lignin. The band at $1650 \mathrm{~cm}^{-1}$ in the IR spectrum of cellulose was possibly caused by adsorbed $\mathrm{H}_{2} \mathrm{O}$. Higher absorption at $3367 \mathrm{~cm}^{-1}$ was also observed because of the moisture content in the biomass. In addition, the bands due to symmetric $\mathrm{CH}_{2}$ bending vibration in cellulose, carboxyl vibration in glucuronic acid with xylan, and $\mathrm{C}-\mathrm{H}$ in plane deformation with aromatic ring stretching in lignin were observed at $1424 \mathrm{~cm}^{-1}$. The IR absorption bands at 1582 and $1508 \mathrm{~cm}^{-1}$ assigned to aromatic ring stretching and vibration $(\mathrm{C}=\mathrm{C}-\mathrm{C})$ in lignin. The band at $1457 \mathrm{~cm}^{-1}$ was observed in lignin due to its $\mathrm{C}-\mathrm{H}$ deformation in methyl and methylene. The $\mathrm{C}-\mathrm{H}$ bending in cellulose, hemicellulose, and lignin (aliphatic $\mathrm{C}-\mathrm{H}$ stretching in methyl and phenolic alcohol) was observed at $1370 \mathrm{~cm}^{-1}$. The $\mathrm{CH}_{2}$ wagging in cellulose and hemicellulose and the $\mathrm{C}-\mathrm{O}$ stretching of $\mathrm{C}_{5}$ substituted aromatic units, such as syringyl and condensed guaiacyl units, were assigned at $1317 \mathrm{~cm}^{-1}$. Similarly, the $\mathrm{C}-\mathrm{O}$ stretching of guaiacyl unit in lignin was assigned at $1235 \mathrm{~cm}^{-1}$. The bands at 1160 and $896 \mathrm{~cm}^{-1}$ arise from C-O-C stretching at the $\beta$-(1 $1 \rightarrow 4)$-glycosidic linkages in cellulose and hemicellulose. The absorption at $1108 \mathrm{~cm}^{-1}$ was associated with aromatic $\mathrm{C}-\mathrm{H}$ in plane deformation for the syringyl unit. The band at $1053 \mathrm{~cm}^{-1}$ was assigned to the $\mathrm{C}-\mathrm{OH}$ stretching vibration of cellulose and hemicellulose. Moreover, this band was for $\mathrm{C}-\mathrm{O}$ deformation in secondary alcohols and aliphatic ethers. The $\mathrm{C}-\mathrm{O}$ stretching of cellulose and primary alcohols and C-H in plane deformation for guaiacyl unit exhibited at $1032 \mathrm{~cm}^{-1}$. Aromatic $\mathrm{C}-\mathrm{H}$ out of plane bending in lignin was presented at $846 \mathrm{~cm}^{-1}$. Although several FTIR bands of different biomass components were overlapped, the IR spectra of samples still provide important clues, including changes of chemical composition, functionalization, and other transformation of biomass for understanding the applied biomass processing.

\subsection{Commonly Used Pretreatment and Preprocessing Solvents}

Table 2 and Figure S1 show the band assignment for common biomass processing solvents. Water is the most common solution in biomass analysis and the conversion processes. It also exists 
in the air, and a certain amount can be accumulated in biomass during its storing and processing. The existence of water in biomass remarkably increased the bands at 3354 and $1653 \mathrm{~cm}^{-1}$ because of its $\mathrm{O}-\mathrm{H}$ stretching and $\mathrm{O}-\mathrm{H}-\mathrm{O}$ scissors bending, respectively [32]. Acetone, ethanol, and methanol are common organic solvents for the diverse pre- and post-processing of biomass, and they are also produced from biomass [33]. Acetone contamination on poplar was observed at 3005, 2908, 1713, 1431,1364 , and $1222 \mathrm{~cm}^{-1}$ representing its $\mathrm{CH}_{3}$ degenerated stretching, $\mathrm{CH}_{3}$ symmetrical stretching, $\mathrm{C}=\mathrm{O}$ stretching, $\mathrm{CH}_{3}$ degenerated deformation, $\mathrm{CH}_{3}$ symmetrical deforming, and $\mathrm{C}-\mathrm{C}$ stretching, respectively [34]. A decrease in the bands at 3354 and $1653 \mathrm{~cm}^{-1}$ is possibly due to the displacement of water in biomass by acetone. The spectra of ethanol impurity were shown at 3350, 2980, and $1056 \mathrm{~cm}^{-1}$ for O-H stretching, C-H stretching, and C-O stretching, and those of methanol were at 3352, 2952, 2879, 1465, 1450, 1336, 1053 and $1026 \mathrm{~cm}^{-1}$ for O-H stretching, C-H stretching (asymmetric), C-H stretching (symmetric), $\mathrm{C}-\mathrm{H}$ bending (asymmetric), $\mathrm{C}-\mathrm{H}$ bending (symmetric), $\mathrm{O}-\mathrm{H}$ bending, $\mathrm{CH}_{3}$ rocking, and C-O stretching, respectively [34-36]. Besides these chemicals, tetrahydrofuran (THF), dioxane, toluene, glycerol, pyridine, and chloroform are well-known solvents for diverse biomass pretreatment, isolation/purification, and analyses [1,3,19,37]. In addition, some chemicals, such as toluene, can be produced from biomass components [38]. The assignments of these impurities were assigned according to the previous studies. Contamination of poplar by THF appeared at 2977 and $2875 \mathrm{~cm}^{-1}$ for its C-H stretching, $1063 \mathrm{~cm}^{-1}$ for ring deformation, and $912 \mathrm{~cm}^{-1}$ for $\mathrm{CH}_{2}$ twisting [39]. The bands of dioxane were observed at 2960, 2890,1457, 1322, 1255, 1119, 1057, 889 and $872 \mathrm{~cm}^{-1}$ to show its equatorial (higher frequency) C-H stretching, axial (lower frequency) $\mathrm{C}-\mathrm{H}$ stretching, symmetric $\mathrm{CH}_{2}$ deformation, $\mathrm{CH}_{2}$ wagging, $\mathrm{CH}_{2}$ twisting, $\mathrm{C}-\mathrm{O}-\mathrm{C}$ symmetric stretching, ring trigonal deformation, $\mathrm{C}-\mathrm{C}$ stretching, and C-O-C stretching, respectively [40]. The addition of toluene on poplar caused three bands including $3069 \mathrm{~cm}^{-1}$ for C-H stretching, $1497 \mathrm{~cm}^{-1}$ for C-C stretching, and $728 \mathrm{~cm}^{-1}$ for C-H out of plane bending [41]. Glycerol on poplar had the bands for O-H stretching at $3341 \mathrm{~cm}^{-1}, \mathrm{C}-\mathrm{H}$ stretching at 2948 and $2897 \mathrm{~cm}^{-1}, \mathrm{C}-\mathrm{H}$ deformation of secondary alcohol at 1333 and $1239 \mathrm{~cm}^{-1}, \mathrm{C}-\mathrm{O}$ stretching of primary alcohol at $1034 \mathrm{~cm}^{-1}$, and $\mathrm{O}-\mathrm{H}$ bending at $923 \mathrm{~cm}^{-1}[42,43]$. Chloroform contaminants also showed at 1220 and $755 \mathrm{~cm}^{-1}$ for $\mathrm{C}-\mathrm{H}$ bending and $\mathrm{CCl}_{3}$ stretching [34]. Pyridine contamination resulted in additional bands for C-H stretching at $3036 \mathrm{~cm}^{-1}, \mathrm{C}-\mathrm{C}$ bonding at $1583 \mathrm{~cm}^{-1}, \mathrm{C}-\mathrm{N}$ stretching at $1485 \mathrm{~cm}^{-1}, \mathrm{C}-\mathrm{H}$ in plane wagging at $1438 \mathrm{~cm}^{-1}$, symmetric $\mathrm{C}-\mathrm{H}$ wagging at $1203 \mathrm{~cm}^{-1}, \mathrm{C}-\mathrm{H}$ wagging at $1069 \mathrm{~cm}^{-1}, \mathrm{C}-\mathrm{C}$ in plane wagging at $1032 \mathrm{~cm}^{-1}, \mathrm{C}-\mathrm{H}$ out of plane bending at 750 and $693 \mathrm{~cm}^{-1}$ [44,45]. The intensities of the bands at 3353 and $1653 \mathrm{~cm}^{-1}$ decreased with the contaminants that do not contain $\mathrm{OH}$ groups such as acetone, THF, dioxane, toluene, chloroform, and pyridine due to the displacement of moisture in biomass by these solvents. On the other hand, the intensity increased with the contaminants having $\mathrm{OH}$ groups such as water, ethanol, methanol, and glycerol.

Table 2. FTIR band assignments of common biomass processing solvents on poplar [32-45].

\begin{tabular}{ccc}
\hline Contaminants & Wavenumber $\left[\mathrm{cm}^{-\mathbf{1}}\right]$ & Assignments \\
\hline \multirow{2}{*}{ Water } & 3354 & $\mathrm{O}-\mathrm{H}$ stretching \\
& 1653 & $\mathrm{O}-\mathrm{H}-\mathrm{O}$ scissors bending \\
& 3005 & $\mathrm{CH}_{3}$ stretching \\
& 2908 & $\mathrm{CH}_{3}$ stretching \\
Acetone & 1713 & $\mathrm{C}=\mathrm{O}$ stretching \\
& 1431 & $\mathrm{CH}_{3}$ deforming \\
& 1364 & $\mathrm{CH}_{3}$ deforming \\
& 1222 & $\mathrm{C}-\mathrm{C}$ stretching \\
Ethanol & 3350 & $\mathrm{O}-\mathrm{H}$ stretching \\
& 2980 & $\mathrm{C}-\mathrm{H}$ stretching \\
& 1056 & $\mathrm{C}-\mathrm{O}$ stretching \\
\hline
\end{tabular}


Table 2. Cont.

\begin{tabular}{|c|c|c|}
\hline Contaminants & Wavenumber $\left[\mathrm{cm}^{-1}\right]$ & Assignments \\
\hline \multirow{8}{*}{ Methanol } & 3352 & O-H stretching \\
\hline & 2952 & $\mathrm{C}-\mathrm{H}$ asymmetric stretching \\
\hline & 2879 & C-H symmetric stretching \\
\hline & 1465 & $\mathrm{C}-\mathrm{H}$ asymmetric bending \\
\hline & 1450 & C-H symmetric bending \\
\hline & 1336 & $\mathrm{O}-\mathrm{H}$ bending \\
\hline & 1068 & $\mathrm{CH}_{3}$ rocking \\
\hline & 1026 & C-O stretching \\
\hline \multirow{4}{*}{ Tetrahydrofuran } & 2977 & $\mathrm{C}-\mathrm{H}$ stretching \\
\hline & 2875 & C-H stretching \\
\hline & 1063 & Ring deformation \\
\hline & 912 & $\mathrm{CH}_{2}$ twisting \\
\hline \multirow{4}{*}{ Toluene } & 3069 & C-H stretching \\
\hline & 1497 & C-C stretching \\
\hline & 728 & $\mathrm{C}-\mathrm{H}$ out of plane bending \\
\hline & 2960 & C-H stretching \\
\hline \multirow{8}{*}{ Dioxane } & 2890 & C-H stretching \\
\hline & 1457 & Symmetric $\mathrm{CH}_{2}$ deformation \\
\hline & 1322 & $\mathrm{CH}_{2}$ wagging \\
\hline & 1255 & $\mathrm{CH}_{2}$ twisting \\
\hline & 1119 & C-O-C symmetric stretching \\
\hline & 1057 & Ring trigonal deformation \\
\hline & 889 & C-C stretching \\
\hline & 872 & $\mathrm{C}-\mathrm{O}-\mathrm{C}$ stretching \\
\hline \multirow{7}{*}{ Glycerol } & 3341 & $\mathrm{O}-\mathrm{H}$ bending \\
\hline & 2948 & C-H stretching \\
\hline & 2897 & $\mathrm{C}-\mathrm{H}$ stretching \\
\hline & 1333 & C-H deformation \\
\hline & 1239 & C-H deformation \\
\hline & 1034 & C-O stretching \\
\hline & 923 & $\mathrm{O}-\mathrm{H}$ bending \\
\hline \multirow{3}{*}{ Chloroform } & 1220 & $\mathrm{C}-\mathrm{H}$ bending \\
\hline & 755 & $\mathrm{CCl}_{3}$ stretching \\
\hline & 3036 & $\mathrm{C}-\mathrm{H}$ stretching \\
\hline \multirow{7}{*}{ Pyridine } & 1583 & C-C bonding \\
\hline & 1485 & C-N stretching \\
\hline & 1438 & $\mathrm{C}-\mathrm{H}$ in plane wagging \\
\hline & 1203 & Symmetric C-H wagging \\
\hline & 1069 & C-H wagging \\
\hline & 1032 & C-C in plane wagging \\
\hline & $750 / 693$ & $\mathrm{C}-\mathrm{H}$ out of plane bending \\
\hline
\end{tabular}

\subsection{Acids and Alkalis}

Sulfuric acid, hydrochloric acid, acetic acid, phosphoric acid, ammonium hydroxide, and sodium hydroxide on the poplar sample were observed. As Table 3 and Figure S2 present, most acids on poplar, including sulfuric acid, hydrochloric acid, and phosphoric acid, commonly had the bands at 3370 and $1660 \mathrm{~cm}^{-1}$ to represent $\mathrm{O}-\mathrm{H}$ bonding and $\mathrm{O}-\mathrm{H}-\mathrm{O}$ scissors bending, respectively, because of water content. The contamination bands from sulfuric acid in the literature at 1362 and $750 \mathrm{~cm}^{-1}$ for $\mathrm{S}=\mathrm{O}$ $\left(1362 \mathrm{~cm}^{-1}\right)$ and S-O stretching $\left(750 \mathrm{~cm}^{-1}\right)$ were not clearly appeared in this study [46]. A relatively low concentration of sulfuric acid (4\%) could be the reason for weak intensities of the contaminant. Hydrochloric acid showed $\mathrm{H}-\mathrm{Cl}$ stretching at $2942 \mathrm{~cm}^{-1}$, while phosphoric acid had a P-OH bond and $\mathrm{P}=\mathrm{O}$ stretching at 2904 and $1161 \mathrm{~cm}^{-1}$, respectively [34,47,48]. Acetic acid bands appeared at $3351,2916,1706,1427,1234$, and $1031 \mathrm{~cm}^{-1}$ to indicate its $\mathrm{O}-\mathrm{H}$ stretching, symmetric $\mathrm{CH}_{3}$ stretching, $\mathrm{C}=\mathrm{O}$ stretching, $\mathrm{CH}_{3}$ deformation, $\mathrm{O}-\mathrm{H}$ bending and $\mathrm{CH}_{3}$ rocking, respectively [34]. Sodium hydroxide 
had the bands caused by water at 3360 and $1660 \mathrm{~cm}^{-1}$, but there were no other clear contamination bands observed. Similarly, ammonium hydroxide had the IR bands at 3350 and $1660 \mathrm{~cm}^{-1}$ from both water and $\mathrm{NH}_{3}$ content but N-H stretching of $\mathrm{NH}_{4}{ }^{+}$also appeared at $2914 \mathrm{~cm}^{-1}$. Previous study also said that adsorption of ammonia increased the overall polarity and resulted in the absorbance of several bands (e.g., 1115 and $1036 \mathrm{~cm}^{-1}$ in this study) not from the N-H vibrations [49].

Table 3. FTIR band assignments of acids and alkalis contaminants on poplar [34,46-49].

\begin{tabular}{ccc}
\hline Contaminants & Wavenumber $\left[\mathbf{c m}^{-1}\right]$ & Assignments \\
\hline \multirow{3}{*}{ Sulfuric acid } & 3370 & O-H stretching \\
& 1660 & O-H-O scissors bending \\
Hydrochloric acid & 1362 & S=O stretching \\
& 350 & S-O stretching \\
& 2905 & O-H stretching \\
Phosphoric acid & 1660 & $\mathrm{H}-\mathrm{Cl}$ stretching \\
& 3370 & O-H-O scissors bending \\
& 1605 & O-H stretching \\
& 1161 & P-OH bond \\
Acetic acid & 1031 & O-H-O scissors bending \\
& 3351 & $\mathrm{P}=\mathrm{O}$ stretching \\
& 2916 & $\mathrm{P}=\mathrm{O}$ stretching \\
& 1706 & $\mathrm{O}-\mathrm{H}$ stretching \\
& 1427 & Symmetric CH $\mathrm{H}_{3}$ stretching \\
& 1234 & $\mathrm{C}=\mathrm{O}$ stretching \\
& 1031 & $\mathrm{CH}$ deformation \\
& 3350 & $\mathrm{O}-\mathrm{H}$ bending \\
& 2914 & $\mathrm{CH}$ rocking \\
& 1660 & $\mathrm{~N}-\mathrm{H}$ stretching \& O-H stretching \\
\hline
\end{tabular}

\subsection{Ionic Liquids}

Besides the aforementioned chemicals, FTIR spectra and the band assignments of ionic liquids, enzymes, and biomass-derived chemicals on poplar are presented in Table 4 and Figures S3-S5. The bands from 1-butyl-3-methylimidazolium chloride contaminant were observed at 3341, 1658, and $1604 \mathrm{~cm}^{-1}$ representing the formation of quaternary amine salt formation with chlorine, $\mathrm{C}=\mathrm{C}$ stretching, and $\mathrm{C}=\mathrm{N}$ stretching, respectively. However, the band at $835 \mathrm{~cm}^{-1}$ representing C-N stretching vibration was not clearly observed [50]. The bands from 1-benzyl-3-methylimidazolium chloride were 2961, 1574, 765, and $633 \mathrm{~cm}^{-1}$ from C-H stretching, C-C stretching of ring vibration, and C-N/C-Cl in-plane bending, respectively [51]. Moreover, two bands at 1383 and $1176 \mathrm{~cm}^{-1}$ were observed; however, further study is needed to identify them.

Table 4. FTIR band assignments of ionic liquids, enzymes, and biomass-derived chemicals on poplar [49-65].

\begin{tabular}{ccl}
\hline Contaminants & Wavenumber $\left[\mathrm{cm}^{-\mathbf{1}}\right]$ & Assignments \\
\hline & 3341 & Quaternary amine salt formation \\
1-Butyl-3-methylimidazolium chloride & 1658 & C=C stretching \\
& 1604 & C=N stretching \\
1-Benzyl-3-methylimidazolium chloride & 2961 & C-H stretching \\
& 1574 & C-C stretching ring vibration \\
& 633 & C-N/C-Cl in-plane bending \\
\hline
\end{tabular}


Table 4. Cont.

\begin{tabular}{|c|c|c|}
\hline Contaminants & Wavenumber $\left[\mathrm{cm}^{-1}\right]$ & Assignments \\
\hline \multirow{9}{*}{ ChCl-Urea } & 3435 & $\mathrm{NH}_{2}$ asymmetric stretching \\
\hline & 3340 & $\mathrm{NH}_{2}$ symmetric stretching \\
\hline & 1669 & $\mathrm{NH}_{2}$ bending vibration \\
\hline & 1597 & $\mathrm{OH}$ bending vibration \\
\hline & 1474 & $\mathrm{CH}_{3}$ rocking \\
\hline & 1152 & C-N stretching \\
\hline & 1062 & $\mathrm{CH}_{2}$ rocking \\
\hline & 961 & Asymmetric stretching of $\mathrm{COO}$ \\
\hline & 790 & $\mathrm{C}=\mathrm{O}$ bonding \\
\hline \multirow{9}{*}{ ChCl-PHA } & 3180 & $\mathrm{O}-\mathrm{H}$ stretching \\
\hline & 1681 & $\mathrm{C}=\mathrm{O}$ stretching \\
\hline & 1581 & Asymmetric stretching of $\mathrm{COO}$ \\
\hline & 1282 & C-O stretching vibration \\
\hline & 1082 & C-O stretching \\
\hline & 953 & C-N stretching \\
\hline & 861 & $\mathrm{CH}_{2}$ rocking vibrations \\
\hline & 838 & Aromatic C-H out-of-plane bending \\
\hline & 786 & $\mathrm{C}-\mathrm{C}$ stretching \\
\hline \multirow{4}{*}{$\mathrm{ChCl-PB}$} & 3122 & The stretching vibration of the phenolic $\mathrm{O}-\mathrm{H}$ \\
\hline & 1667 & The stretching vibration of carbonyl group \\
\hline & 1272 & Methylene \\
\hline & 1030 & $\mathrm{C}-\mathrm{H}$ binding \\
\hline \multirow{6}{*}{$\mathrm{ChCl-PCA}$} & 3126 & Bending vibration of $-\mathrm{NH}_{2}$ \\
\hline & 1675 & $\mathrm{C}=\mathrm{O}$ stretch of carboxylic acid \\
\hline & 1606 & $\mathrm{C}=\mathrm{C}$ stretching \\
\hline & 1160 & $\mathrm{C}-\mathrm{OH}$ stretching \\
\hline & 848 & $\mathrm{C}-\mathrm{H}$ stretching \\
\hline & 771 & Stretching of the -OH group \\
\hline \multirow{6}{*}{ Cellulase } & 3353 & N-H stretching \& O-H stretching \\
\hline & 2942 & $\mathrm{C}-\mathrm{H}$ stretching (asymmetric) \\
\hline & 2900 & $\mathrm{C}-\mathrm{H}$ stretching (symmetric) \\
\hline & 1642 & $\mathrm{NH}_{2}$ scissoring \& $\mathrm{C}=\mathrm{N}$ vibration \\
\hline & 1334 & C-N stretching \\
\hline & 1036 & C-N stretching \\
\hline \multirow{4}{*}{$\beta$-glucosidase } & 3351 & $\mathrm{~N}-\mathrm{H}$ stretching \\
\hline & 1646 & $\mathrm{~N}-\mathrm{H}$ bonding \& $\mathrm{C}=\mathrm{O}$ stretching \\
\hline & 1432 & N-H stretching \\
\hline & 620 & $\mathrm{~N}-\mathrm{H}$ out of plane bending \\
\hline \multirow{3}{*}{ HMF } & 3364 & $\mathrm{O}-\mathrm{H}$ stretching \\
\hline & 1661 & Carbonyl stretching \\
\hline & 1561 & $\mathrm{C}=\mathrm{C}$ stretching (furan ring) \\
\hline \multirow{6}{*}{ Furfural } & 3134 & $\mathrm{C}-\mathrm{H}$ stretching \\
\hline & 2859 & $\mathrm{C}-\mathrm{H}$ vibration of aldehyde group \\
\hline & 1671 & $\mathrm{C}=\mathrm{O}$ in conjugated carbonyl group \\
\hline & 1465 & $\mathrm{C}=\mathrm{C}$ stretching of furan ring \\
\hline & $1276 / 1021$ & C-O stretching vibration \\
\hline & $928 / 884 / 755$ & $\mathrm{C}-\mathrm{H}$ bending out of plane peaks \\
\hline
\end{tabular}

The bands of choline chloride-urea, which is a well-known DES, were at 3435 and $3340 \mathrm{~cm}^{-1}$, which ascribed to the stretching of $-\mathrm{NH}_{2}$ (asymmetric and symmetric), $1669 \mathrm{~cm}^{-1}$ for the bending vibration of $-\mathrm{NH}_{2}, 1597 \mathrm{~cm}^{-1}$ for bending vibration of $-\mathrm{OH}$ possibly due to the existence of water, $1474 \mathrm{~cm}^{-1}$ for $\mathrm{CH}_{3}$ rocking, $1152 \mathrm{~cm}^{-1}$ for asymmetric C-N stretching, $1062 \mathrm{~cm}^{-1}$ for $\mathrm{CH}_{2}$ rocking, $961 \mathrm{~cm}^{-1}$ for asymmetric stretching of $\mathrm{CCO}$ from choline structure and $790 \mathrm{~cm}^{-1}$ from $\mathrm{C}=\mathrm{O}$ bonding $[52,53]$. Three lignin-based DESs, choline chloride- $p$-hydroxybenzoic acid (PHA), choline chloride-4-hydroxybenzaldehyde (PB), and choline chloride- $p$-coumaric acid (PCA), were mixed with poplar sample to observe the possible contamination bands. The bands of choline chloride-PHA were observed at $3180 \mathrm{~cm}^{-1}$ for O-H stretching, $1681 \mathrm{~cm}^{-1}$ for $\mathrm{C}=\mathrm{O}$ stretching, $1581 \mathrm{~cm}^{-1}$ for the asymmetric stretch of COO vibrations, $1282 \mathrm{~cm}^{-1}$ for C-O stretching vibration, $1082 \mathrm{~cm}^{-1}$ for C-O stretching, $953 \mathrm{~cm}^{-1}$ for $\mathrm{C}-\mathrm{N}$ stretching, $861 \mathrm{~cm}^{-1}$ for $\mathrm{CH}_{2}$ rocking vibrations, $838 \mathrm{~cm}^{-1}$ for aromatic $\mathrm{C}-\mathrm{H}$ 
out-of-plane bending, $786 \mathrm{~cm}^{-1}$ for $\mathrm{C}-\mathrm{C}$ stretching $[54,55]$. The bands from choline chloride-PB were observed at $3122 \mathrm{~cm}^{-1}$ for the stretching vibration of the phenolic $\mathrm{O}-\mathrm{H}$ group exhibiting intermolecular hydrogen bonding, $1667 \mathrm{~cm}^{-1}$ for the stretching vibration of carbonyl group, $1272 \mathrm{~cm}^{-1}$ for the methylene, $1030 \mathrm{~cm}^{-1}$ for C-H binding vibration [56]. The bands from choline chloride-PCA DES were observed at $3126 \mathrm{~cm}^{-1}, 1675 \mathrm{~cm}^{-1}, 1606 \mathrm{~cm}^{-1}, 1160 \mathrm{~cm}^{-1}, 848 \mathrm{~cm}^{-1}$ from bending vibration of $-\mathrm{NH}_{2}, \mathrm{C}=\mathrm{O}$ stretch of carboxylic acid, $\mathrm{C}=\mathrm{C}$ stretching, $\mathrm{C}-\mathrm{OH}$ stretching, $\mathrm{C}-\mathrm{H}$ stretching and $771 \mathrm{~cm}^{-1}$ from stretching of the $-\mathrm{OH}$ group on the second carbon of the choline chloride [57-59].

\subsection{Enzymes}

Enzymes such as cellulase and $\beta$-glucosidase break polysaccharides in biomass to fermentable sugars. The bands at 3353, 2942, 2900,1642, 1334, and $1036 \mathrm{~cm}^{-1}$ were observed from cellulase (Table 4 and Figure S4). The bands at 3353, 2942, and $2900 \mathrm{~cm}^{-1}$ were from N-H/O-H stretching and the C-H stretching (asymmetric and symmetric) of cellulase. The bands at 1642, 1432, 1334, and $1036 \mathrm{~cm}^{-1}$ were possibly from $\mathrm{NH}_{2}$ scissoring, $\mathrm{C}-\mathrm{C}$ stretching, $\mathrm{C}-\mathrm{N}$ stretching, and C-O stretching, respectively [60-62]. $\beta$-glucosidase also showed similar bands at 3351,1646,1432, and $620 \mathrm{~cm}^{-1}$, which represented $\mathrm{N}-\mathrm{H}$ stretching, $\mathrm{N}-\mathrm{H}$ bonding and $\mathrm{C}=\mathrm{O}$ stretching, $\mathrm{N}-\mathrm{H}$ bending, and $\mathrm{N}-\mathrm{H}$ out of plane bending, respectively [63].

\subsection{Biomass-Derived Chemicals}

Biomass can be contaminated by its decomposed fractions. For instance, furan-based chemicals such as furfural and hydroxymethylfurfural can be produced through the dehydration of hexoses and pentoses in biomass. As Figure S5 presents, HMF contamination showed at 3364, 1661, and $1561 \mathrm{~cm}^{-1}$ from O-H stretching, $\mathrm{C}=\mathrm{O}$ stretching (carbonyl), and $\mathrm{C}=\mathrm{C}$ stretching of furan ring, respectively [64]. Furfural also showed bands at $3134 \mathrm{~cm}^{-1}$ from C-H stretching of furan ring, at $2859 \mathrm{~cm}^{-1}$ from the C-H vibration of aldehyde group, $1671 \mathrm{~cm}^{-1}$ from $\mathrm{C}=\mathrm{O}$ in the conjugated carbonyl group, $1465 \mathrm{~cm}^{-1}$ from $\mathrm{C}=\mathrm{C}$ stretching of furan ring, 1276 and $1021 \mathrm{~cm}^{-1}$ from C-O stretching vibration, 928, 884, and $755 \mathrm{~cm}^{-1}$ from C-H bending out of plane peaks $[65,66]$.

\section{Conclusions}

The identification of contaminants on the biomass surface after preprocessing is important to avoid the unwanted misleading of analysis data. This study investigated and discussed diagnostic FTIR bands from 26 potential chemicals, including organic solvents, acids and alkalis, ionic liquids, enzymes, and biomass-derived components through diverse biomass preprocessing. The observation of these contaminants will improve the FTIR analysis with diverse biomass and bioproducts in the biorefinery.

Supplementary Materials: The following are available online at http://www.mdpi.com/2076-3417/10/12/4345/s1, Figure S1: FTIR spectra of preprocessing solvent contaminants on poplar, Figure S2: FTIR spectra of preprocessing acid and alkaline contaminants on poplar, Figure S3: FTIR spectra of ionic liquid contaminants on poplar, Figure S4: FTIR spectra of enzyme contaminants on poplar, Figure S5: FTIR spectra of biomass-derived chemical contaminants on poplar.

Author Contributions: C.G.Y. and A.J.R. conceived and designed the research. J.Z., C.G.Y., M.L., and Y.P. carried out the experiment. J.Z., M.L., and C.G.Y. wrote the manuscript. All the authors discussed data and revised the paper. All authors have given approval to the final version of the manuscript.

Funding: This research received no external funding.

Acknowledgments: This manuscript has been authored by UT-Battelle, LLC under Contract No. DE-AC0500OR22725 with the U.S. Department of Energy. This study was supported and performed as part of the BioEnergy Science Center (BESC) and Center for Bioenergy Innovation (CBI). The BESC and CBI are U.S. Department of Energy Bioenergy Research Centers supported by the Office of Biological and Environmental Research in the DOE Office of Science. The United States Government retains and the publisher, by accepting the article for publication, acknowledges that the United States Government retains a non-exclusive, paid-up, irrevocable, world-wide license to publish or reproduce the published form of this manuscript, or allow others to do so, for the United States Government purposes. The Department of Energy will provide public access to these results of federally sponsored research in accordance with the DOE Public Access Plan (http://energy.gov/downloads/doe-public-access-plan). 
The views and opinions of the authors expressed herein do not necessarily state or reflect those of the United States Government or any agency thereof. Neither the United States Government nor any agency thereof, nor any of their employees, makes any warranty, expressed or implied, or assumes any legal liability or responsibility for the accuracy, completeness, or usefulness of any information, apparatus, product, or process disclosed, or represents that its use would not infringe privately owned rights. The views and opinions of the authors expressed herein do not necessarily state or reflect those of the United States Government or any agency thereof. Neither the United States Government nor any agency thereof, nor any of their employees, makes any warranty, expressed or implied, or assumes any legal liability or responsibility for the accuracy, completeness, or usefulness of any information, apparatus, product, or process disclosed, or represents that its use would not infringe privately owned rights.

Conflicts of Interest: There are no conflicts to declare.

\section{References}

1. $\mathrm{Pu}, \mathrm{Y}$;; Cao, S.; Ragauskas, A.J. Application of quantitative 31P NMR in biomass lignin and biofuel precursors characterization. Energy Environ. Sci. 2011, 4, 3154-3166. [CrossRef]

2. Yoo, C.G.; Pu, Y.; Li, M.; Ragauskas, A.J. Elucidating Structural Characteristics of Biomass using Solution-State 2D NMR with a Mixture of Deuterated Dimethylsulfoxide and Hexamethylphosphoramide. ChemSusChem 2016, 9, 1090-1095. [CrossRef] [PubMed]

3. Yoo, C.G.; Yang, Y.; Pu, Y.; Meng, X.; Muchero, W.; Yee, K.L.; Thompson, O.A.; Rodriguez, M.; Bali, G.; Engle, N.L. Insights of biomass recalcitrance in natural Populus trichocarpa variants for biomass conversion. Green Chem. 2017, 19, 5467-5478. [CrossRef]

4. Sluiter, A.; Hames, B.; Ruiz, R.; Scarlata, C.; Sluiter, J.; Templeton, D.; Crocker, D. Determination of structural carbohydrates and lignin in biomass. Lab. Anal. Proced. 2010, 1617, 1-16.

5. Jung, S.; Foston, M.; Kalluri, U.C.; Tuskan, G.A.; Ragauskas, A.J. 3D chemical image using TOF-SIMS revealing the biopolymer component spatial and lateral distributions in biomass. Angew. Chem. 2012, 124, 12171-12174. [CrossRef]

6. Tolbert, A.K.; Yoo, C.G.; Ragauskas, A.J. Understanding the Changes to Biomass Surface Characteristics after Ammonia and Organosolv Pretreatments by Using Time-of-Flight Secondary-Ion Mass Spectrometry (TOF-SIMS). ChemPlusChem 2017, 82, 686-690. [CrossRef]

7. Sannigrahi, P.; Kim, D.H.; Jung, S.; Ragauskas, A. Pseudo-lignin and pretreatment chemistry. Energy Environ. Sci. 2011, 4, 1306-1310. [CrossRef]

8. Figueira, M.; Volesky, B.; Mathieu, H. Instrumental analysis study of iron species biosorption by Sargassum biomass. Environ. Sci. Technol. 1999, 33, 1840-1846. [CrossRef]

9. Kok, M.V.; Özgür, E. Thermal analysis and kinetics of biomass samples. Fuel Process. Technol. 2013, 106, 739-743. [CrossRef]

10. Pu, Y.; Meng, X.; Yoo, C.G.; Li, M.; Ragauskas, A.J. Analytical methods for biomass characterization during pretreatment and bioconversion. In Valorization of Lignocellulosic Biomass in a Biorefinery: From Logistics to Environmental and Performance Impact; Kumar, R., Ed.; Nova Science Publishers: New York, NY, USA, 2016; pp. 37-78.

11. Acquah, G.E.; Via, B.K.; Fasina, O.O.; Eckhardt, L.G. Rapid quantitative analysis of forest biomass using fourier transform infrared spectroscopy and partial least squares regression. J. Anal. Methods Chem. 2016, 2016, 1839598. [CrossRef]

12. Perkins, W. Fourier transform infrared spectroscopy. Part II. Advantages of FT-IR. J. Chem. Educ. 1987, 64, A269. [CrossRef]

13. Di Fidio, N.; Raspolli Galletti, A.M.; Fulignati, S.; Licursi, D.; Liuzzi, F.; De Bari, I.; Antonetti, C. Multi-Step Exploitation of Raw Arundo donax L. for the Selective Synthesis of Second-Generation Sugars by Chemical and Biological Route. Catalysts 2020, 10, 79. [CrossRef]

14. Licursi, D.; Antonetti, C.; Fulignati, S.; Corsini, A.; Boschi, N.; Galletti, A.M.R. Smart valorization of waste biomass: Exhausted lemon peels, coffee silverskins and paper wastes for the production of levulinic acid. Chem. Eng. Trans. 2018, 65, 637.

15. Lara-Serrano, M.; Morales-delaRosa, S.; Campos-Martín, J.M.; Fierro, J.L.G. Fractionation of Lignocellulosic Biomass by Selective Precipitation from Ionic Liquid Dissolution. Appl. Sci. 2019, 9, 1862. [CrossRef] 
16. Shen, X.J.; Wen, J.L.; Mei, Q.Q.; Chen, X.; Sun, D.; Yuan, T.Q.; Sun, R.C. Facile fractionation of lignocelluloses by biomass-derived deep eutectic solvent (DES) pretreatment for cellulose enzymatic hydrolysis and lignin valorization. Green Chem. 2019, 21, 275-283. [CrossRef]

17. Agbor, V.B.; Cicek, N.; Sparling, R.; Berlin, A.; Levin, D.B. Biomass pretreatment: Fundamentals toward application. Biotechnol. Adv. 2011, 29, 675-685. [CrossRef] [PubMed]

18. Yoo, C.G.; Pu, Y.; Ragauskas, A.J. Ionic liquids: Promising green solvents for lignocellulosic biomass utilization. Curr. Opin. Green Sustain. Chem. 2017, 5, 5-11. [CrossRef]

19. Nguyen, T.Y.; Cai, C.M.; Osman, O.; Kumar, R.; Wyman, C.E. CELF pretreatment of corn stover boosts ethanol titers and yields from high solids SSF with low enzyme loadings. Green Chem. 2016, 18, 1581-1589. [CrossRef]

20. Yang, B.; Dai, Z.; Ding, S.-Y.; Wyman, C.E. Enzymatic hydrolysis of cellulosic biomass. Biofuels 2011, 2, 421-449. [CrossRef]

21. Rasmussen, H.; Sørensen, H.R.; Meyer, A.S. Formation of degradation compounds from lignocellulosic biomass in the biorefinery: Sugar reaction mechanisms. Carbohydr. Res. 2014, 385, 45-57. [CrossRef]

22. Li, M.; Pu, Y.; Yoo, C.G.; Gjersing, E.; Decker, S.R.; Doeppke, C.; Shollenberger, T.; Tschaplinski, T.J.; Engle, N.L.; Sykes, R.W. Study of traits and recalcitrance reduction of field-grown COMT down-regulated switchgrass. Biotechnol. Biofuels 2017, 10, 12. [CrossRef] [PubMed]

23. Faix, O. Fourier transform infrared spectroscopy. In Methods in Lignin Chemistry; Lin, S.Y., Dence, C.W., Eds.; Springer: Berlin/Heidelberg, Germany, 1992; pp. 83-109.

24. Sim, S.F.; Mohamed, M.; Lu, N.A.L.M.I.; Sarman, N.S.P.; Samsudin, S.N.S. Computer-assisted analysis of fourier transform infrared (FTIR) spectra for characterization of various treated and untreated agriculture biomass. BioResources 2012, 7, 5367-5380. [CrossRef]

25. Pandey, K. A study of chemical structure of soft and hardwood and wood polymers by FTIR spectroscopy. J. Appl. Polym. Sci. 1999, 71, 1969-1975. [CrossRef]

26. Ciolacu, D.; Ciolacu, F.; Popa, V.I. Amorphous cellulose-Structure and characterization. Cell. Chem. Technol. 2011, 45, 13.

27. Yang, H.; Yan, R.; Chen, H.; Lee, D.H.; Zheng, C. Characteristics of hemicellulose, cellulose and lignin pyrolysis. Fuel 2007, 86, 1781-1788. [CrossRef]

28. Le, D.M.; Nielsen, A.D.; Sørensen, H.R.; Meyer, A.S. Characterisation of Authentic Lignin Biorefinery Samples by Fourier Transform Infrared Spectroscopy and Determination of the Chemical Formula for Lignin. Bioenergy Res. 2017, 10, 1025-1035. [CrossRef]

29. Liu, C.F.; Xu, F.; Sun, J.X.; Ren, J.L.; Curling, S.; Sun, R.C.; Fowler, P.; Baird, M.S. Physicochemical characterization of cellulose from perennial ryegrass leaves (Lolium perenne). Carbohydr. Res. 2006, 341, 2677-2687. [CrossRef]

30. Xu, F.; Sun, J.-X.; Sun, R.; Fowler, P.; Baird, M.S. Comparative study of organosolv lignins from wheat straw. Ind. Crop. Prod. 2006, 23, 180-193. [CrossRef]

31. Sills, D.L.; Gossett, J.M. Using FTIR to predict saccharification from enzymatic hydrolysis of alkali-pretreated biomasses. Biotechnol. Bioeng. 2012, 109, 353-362. [CrossRef]

32. Mojet, B.L.; Ebbesen, S.D.; Lefferts, L. Light at the interface: The potential of attenuated total reflection infrared spectroscopy for understanding heterogeneous catalysis in water. Chem. Soc. Rev. 2010, 39, 4643-4655. [CrossRef]

33. Zhang, K.; Pei, Z.; Wang, D. Organic solvent pretreatment of lignocellulosic biomass for biofuels and biochemicals: A review. Bioresour. Technol. 2016, 199, 21-33. [CrossRef] [PubMed]

34. The Virtual Planetary Laboratory Molecular Database. Available online: http://vpl.astro.washington.edu/ spectra/allmoleculeslist.htm (accessed on 8 May 2020).

35. Plyler, E.K. Infrared Spectra of Methanol, Ethanol, and n-Propanol. J. Res. Natl. Bur. Stand. 1952, 48, $281-286$. [CrossRef]

36. Conklin, A., Jr.; Goldcamp, M.J.; Barrett, J. Determination of ethanol in gasoline by FT-IR spectroscopy. J. Chem. Educ. 2014, 91, 889-891. [CrossRef]

37. Hu, S.; Li, Y. Two-step sequential liquefaction of lignocellulosic biomass by crude glycerol for the production of polyols and polyurethane foams. Bioresour. Technol. 2014, 161, 410-415. [CrossRef] [PubMed]

38. Elfadly, A.; Zeid, I.; Yehia, F.; Abouelela, M.; Rabie, A. Production of aromatic hydrocarbons from catalytic pyrolysis of lignin over acid-activated bentonite clay. Fuel Process. Technol. 2017, 163, 1-7. [CrossRef] 
39. Dwivedi, A.; Baboo, V.; Bajpai, A. Fukui Function Analysis and Optical, Electronic, and Vibrational Properties of Tetrahydrofuran and Its Derivatives: A Complete Quantum Chemical Study. J. Theor. Chem. 2015, 2015, 345234. [CrossRef]

40. Borowski, P.; Gac, W.; Pulay, P.; Woliński, K. The vibrational spectrum of 1, 4-dioxane in aqueous solution-theory and experiment. New J. Chem. 2016, 40, 7663-7670. [CrossRef]

41. IR Spectroscopy Tutorial. Available online: https://orgchemboulder.com/Spectroscopy/irtutor/tutorial.shtml (accessed on 8 May 2020).

42. Wen Yee, T.; Tin Sin, L.; Rahman, W.; Samad, A. Properties and interactions of poly (vinyl alcohol)-sago pith waste biocomposites. J. Compos. Mater. 2011, 45, 2199-2209. [CrossRef]

43. Danish, M.; Mumtaz, M.W.; Fakhar, M.; Rashid, U. Response surface methodology based optimized purification of the residual glycerol from biodiesel production process. Chiang Mai J. Sci. 2015, 43, 1570-1582.

44. Swoboda, A.; Kunze, G. Infrared study of pyridine adsorbed on montmorillonite surfaces. Clay Clay Miner. 1964, 13, 277. [CrossRef]

45. Testa, A.C. Molecular Vibrations of Pyridine. Available online: http://facpub.stjohns.edu/ \{\}testaa/anim27vib. html (accessed on 6 May 2020).

46. Segneanu, A.E.; Gozescu, I.; Dabici, A.; Sfirloaga, P.; Szabadai, Z. Organic compounds FT-IR spectroscopy. In Macro To Nano Spectroscopy; Uddin, J., Ed.; InTech: Rijeka, Croatia, 2012; pp. 145-164.

47. Eisazadeh, A.; Kassim, K.A.; Nur, H. Physicochemical characteristics of phosphoric acid stabilized bentonite. Electron. J. Geotech. Eng. 2010, 15, 327-335.

48. Arai, Y.; Sparks, D.L. ATR-FTIR spectroscopic investigation on phosphate adsorption mechanisms at the ferrihydrite-water interface. J. Colloid Interface Sci. 2001, 241, 317-326. [CrossRef]

49. Valentin, R.; Horga, R.; Bonelli, B.; Garrone, E.; Renzo, F.D.; Quignard, F. FTIR spectroscopy of $\mathrm{NH}_{3}$ on acidic and ionotropic alginate aerogels. Biomacromolecules 2006, 7, 877-882. [CrossRef]

50. Dharaskar, S.A.; Varma, M.N.; Shende, D.Z.; Yoo, C.K.; Wasewar, K.L. Synthesis, characterization and application of 1-butyl-3 methylimidazolium chloride as green material for extractive desulfurization of liquid fuel. Sci. World J. 2013, 2013, 395274. [CrossRef] [PubMed]

51. Seethalakshmi, K.; Jasmine Vasantha Rani, E.; Padmavathy, R. Study of vibrational spectra and solvation number of non-aqueous solutions of 1-benzyl-3-dimethylimidazolium chloride through ultrasonic technique. Int. J. Recent Sci. Res. 2015, 6, 2347-2349.

52. Yue, D.; Jia, Y.; Yao, Y.; Sun, J.; Jing, Y. Structure and electrochemical behavior of ionic liquid analogue based on choline chloride and urea. Electrochim. Acta 2012, 65, 30-36. [CrossRef]

53. Du, C.; Zhao, B.; Chen, X.-B.; Birbilis, N.; Yang, H. Effect of water presence on choline chloride-2urea ionic liquid and coating platings from the hydrated ionic liquid. Sci. Rep. 2016, 6, 29225. [CrossRef]

54. Dega-Szafran, Z.; Dutkiewicz, G.; Kosturkiewicz, Z.; Szafran, M. Crystal structure and spectroscopic properties of the complex of trigonelline hydrate with $p$-hydroxybenzoic acid. J. Mol. Struct. 2011, 985, 219-226. [CrossRef]

55. Sun, R.; Tomkinson, J.; Bolton, J. Separation and characterization of lignins from the black liquor of oil palm trunk fiber pulping. Sep. Sci. Technol. 1999, 34, 3045-3058. [CrossRef]

56. Shareef, B.A.; Waheed, I.F.; Jalaot, K.K. Preparation and Analytical Properties of 4-Hydroxybenzaldehyde, Biuret and Formaldehyde Terpolymer Resin. Orient. J. Chem. 2014, 29, 1391-1397. [CrossRef]

57. Kaur, J.; Katopo, L.; Hung, A.; Ashton, J.; Kasapis, S. Combined spectroscopic, molecular docking and quantum mechanics study of $\beta$-casein and p-coumaric acid interactions following thermal treatment. Food Chem. 2018, 252, 163-170. [CrossRef] [PubMed]

58. Moosavinejad, S.M.; Madhoushi, M.; Vakili, M.; Rasouli, D. Evaluation of degradation in chemical compounds of wood in historical buildings using FT-IR and FT-Raman vibrational spectroscopy. Maderas-Cienc. Tecnol. 2019, 21. [CrossRef]

59. Asare, S. Synthesis, Characterization and Molecular Dynamic Simulations of Aqueous Choline Chloride Deep Eutectic Solvents. Ph.D. Thesis, South Dakota State University, Brookings, SD, USA, 2018.

60. Bohara, R.A.; Thorat, N.D.; Pawar, S.H. Immobilization of cellulase on functionalized cobalt ferrite nanoparticles. Korean J. Chem. Eng. 2016, 33, 216-222. [CrossRef]

61. Zhang, D.; Hegab, H.E.; Lvov, Y.; Snow, L.D.; Palmer, J. Immobilization of cellulase on a silica gel substrate modified using a 3-APTES self-assembled monolayer. SpringerPlus 2016, 5, 48. [CrossRef] [PubMed] 
62. Swarnalatha, V.; Ester, R.A.; Dhamodharan, R. Immobilization of $\alpha$-amylase on gum acacia stabilized magnetite nanoparticles, an easily recoverable and reusable support. J. Mol. Catal. B-Enzym. 2013, 96, 6-13. [CrossRef]

63. Bai, H.; Wang, H.; Sun, J.; Irfan, M.; Han, M.; Huang, Y.; Han, X.; Yang, Q. Production, purification and characterization of novel beta glucosidase from newly isolated Penicillium simplicissimum H-11 in submerged fermentation. EXCLI J. 2013, 12, 528.

64. Tsilomelekis, G.; Josephson, T.R.; Nikolakis, V.; Caratzoulas, S. Origin of 5-hydroxymethylfurfural stability in water/dimethyl sulfoxide mixtures. ChemSusChem 2014, 7, 117-126. [CrossRef]

65. Garba, N.A.; Muduru, I.; Sokoto, M.A.; Dangoggo, S.M. Production of liquid hydrocarbons from millet husk via catalytic hydrodeoxygenation in $\mathrm{NIO} / \mathrm{AL}_{2} \mathrm{O}_{3}$ catalysts. In WIT Transactions on Ecology and the Environment; Syngellakis, S., Magaril, E., Eds.; WIT PRESS: Billerica, MA, USA, 2018; pp. 125-130.

66. Allen, G.; Bernstein, H.J. Internal rotation: VIII. The infrared and raman spectra of furfural. Can. J. Chem. 1955, 33, 1055-1061. [CrossRef]

(C) 2020 by the authors. Licensee MDPI, Basel, Switzerland. This article is an open access article distributed under the terms and conditions of the Creative Commons Attribution (CC BY) license (http://creativecommons.org/licenses/by/4.0/). 